\title{
INTENSE PLASTIC DEFORMATION OF HIGH-PURITY CAST BERYLLIUM
}

\author{
A.A. Vasil'ev, S.P. Stetsenko, R.L. Vasilenko, D.G. Malykhin, P.I. Stoyev, S.V. Khovrich, \\ O.V. Trembach. K.V. Kovtun \\ National Science Center "Kharkov Institute of Physics and Technology”, Kharkiv, Ukraine \\ E-mail: kkovtun@kipt.kharkov.ua
}

Studies were made into the effect of severe plastic deformation on the mechanical properties, structure, and texture of high-purity cast beryllium. For the first time, angular pressing of high-purity cast beryllium was carried out at temperatures of 600 and $500{ }^{\circ} \mathrm{C}$. It is shown that the degree of grain refinement during angular pressing into a strip reaches a significant value. In a single deformation cycle, the grain is crushed from $3 \mathrm{~mm}$ down to $10 \mu \mathrm{m}$. Temperature dependences of the mechanical properties of the material of extruded billets in the initial state and after recrystallization annealing at a temperature of $650{ }^{\circ} \mathrm{C}$ for one hour were studied. It has been established that the best mechanical properties are shown by the samples of material deformed at $600{ }^{\circ} \mathrm{C}$ with subsequent annealing at $650{ }^{\circ} \mathrm{C}$ for an hour.

For structure refinement and improving mechanical properties of a wide range of metals and alloys, including the hcp-lattice metals, considerable recent attention has been focused on developing different types of intensive deformation processing [1-4]. Substantial progress in structure refinement has been observed with the development of such a method of intensive deformation processing as the equal-channel angular pressing (ECAP) [5]. It has been demonstrated that in order to create the required properties after the ECAPbased treatment, a wide variety of microstructure parameters, among them the grain sizes and the crystallographic texture, should be controlled. This deformation processing and a further heat treatment may give rise to the formation of the microstructure having the grains and subgrains with equilibrium largeangle boundaries and low defect density in their body. It may be also assumed that at the cost of an increase in the shear mode under deformation of the materials, it would be possible to provide a supplementary plasticity reserve in the materials without compromising their strength.
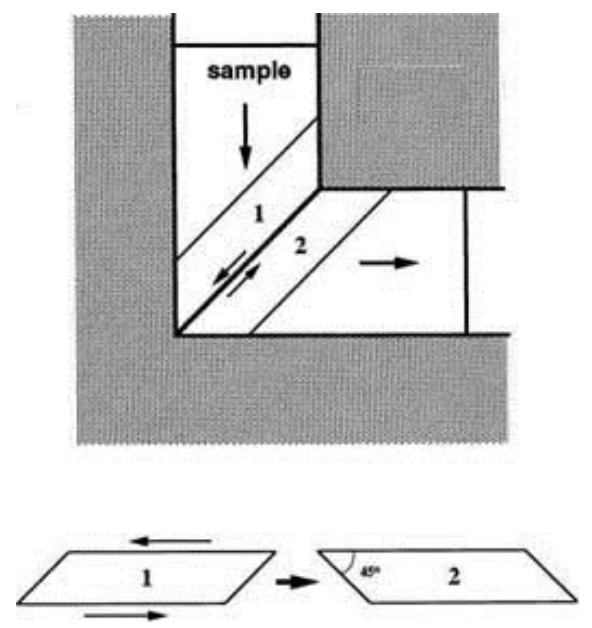

Fig. 1. The ECAP principle showing the shear plane inside the matrix: the elements numbered 1 and 2 move due to the shear, as shown at the bottom of the illustration

The basic diagram showing the principle of the process of deformation at ECAP is given in Fig. 1 [6]. As is clear from the figure, the process material undergoes in this case a substantial shear deformation.

The shear deformation components at angular pressing (AP) realization promote the development of vigorous motion of defects. The active defects sink aids in increasing the grain boundary disorientation up to large-angle boundaries. This situation permits the formation of highly dispersed structures with largeangle boundaries, which are characterized by a high level of plasticity and strength.

As regards beryllium, one of the main factors that restrict its usage is a low plasticity at a temperature below $200^{\circ} \mathrm{C}$. The progress in solving the problem of beryllium cold brittleness is connected mainly with removal of impurities from beryllium and the creation of fine-grained structure through the use of deformation/thermal processing. For a number of beryllium semi-products and workpieces, a satisfactory combination of strength and plasticity may result from the creation of a favorable crystallographic texture by the plastic deformation methods. The grain size reduction in beryllium leads to the improvement of its strength/plasticity characteristics, and also, to the reduction of brittle-ductile transition temperature [7]. However, the formation of fine grains in beryllium is rather difficult to realize, and even in a severely deformed metal after recrystallization annealing the average grain size is no less than 25 to $30 \mu \mathrm{m}$. The investigation of possible structure refinement in beryllium at AP gives tangible grounds for improving mechanical properties of beryllium, particularly, its lowtemperature plasticity.

Previous studies of the effect of severe plastic deformation on the structure and properties of beryllium were performed using the billets obtained by the powder metallurgical practice [8-10]. Those studies have demonstrated that the angular pressing leads to the refinement of beryllium substructure and to the improvement in the values of ultimate strength, yield points, and relative elongation of the billet material. In this case, the preforms before angular pressing have rather fine grains, which are determined by the size of 
the powder and powder metallurgy technology being used, as well as high strength, but limited ductility (relative elongation), especially at room temperature, due to a high content of beryllium oxide precipitates along the grain boundaries. In this study, to restrict influence of beryllium oxide precipitates on the structure and properties of the metal, a high-purity cast metal was first used as initial preforms in AP.

It is expected that its use would be helpful for better elucidation of the structure parameters effect on the properties of the material of billets produced during severe plastic deformation, and will aid in upgrading the metal plasticity at room temperature.

\section{RESEARCH MATERIALS AND METHODS}

A high-purity distilled beryllium ingot served as an initial material for producing billets intended for deformation processing. The residual resistivity ratio of the ingot material at liquid nitrogen temperature was determined to be $\delta \sim 45$.

To grind the initial coarse-grained structure, the ingot was subjected to multidirectional (extrusion sediment) mechanical-thermal treatment in the temperature range between 1000 and $900{ }^{\circ} \mathrm{C}$. After the preliminary deformation processing, cylindrical billets were cut out of the ingot by the electroerosion method for further angular pressing. The billet diameter was $14.5 \mathrm{~mm}$, and the billet length was $40 \mathrm{~mm}$. The billet for deformation at $600{ }^{\circ} \mathrm{C}$ was placed into a steel-20 casing, and for deformation at $500{ }^{\circ} \mathrm{C}$ - into a copper casing. The AP process was realized in accordance with the basic diagram shown in Fig. 1.

The preheating temperature before deformation was set to be 600 and $500{ }^{\circ} \mathrm{C}$, while the forming tool was heated up to $300{ }^{\circ} \mathrm{C}$. After the AP has been performed, the outer shells were etched away in acid. An external view of beryllium strips after removal of metal shells is shown in Fig. 2. The surfaces denoted by the Roman numerals present the top surface for the deformation diagram given in Fig. 1.

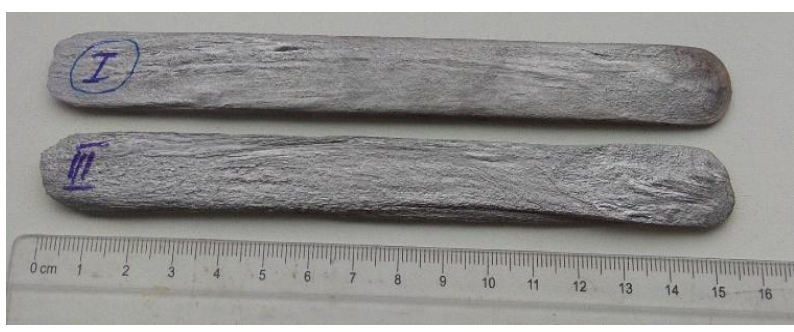

Fig. 2. External view of beryllium strips after extrusion at an angle of $90^{\circ}$ to the applied load direction after deformation at $600^{\circ} \mathrm{C}$ (upper) and $500{ }^{\circ} \mathrm{C}$ (lower)

From the beryllium strips obtained by electrosparking, the samples were cut out for investigating the mechanical properties in tensile tests, for measuring microhardness values on the extruded strip surfaces, and also for texture studies The mechanical properties of beryllium samples were investigated by standard tension-test procedures at temperatures ranging from 20 to $600{ }^{\circ} \mathrm{C}$, using machines for testing at strain rates of $1 \cdot 10^{-3} \mathrm{~s}^{-1}$ in the asdeformed condition and after recrystallization annealing at $650{ }^{\circ} \mathrm{C}$ for $1 \mathrm{~h}$.

In mechanical testing at room temperature, apart from studies into mechanical properties, acoustic emission (AE) spectra were taken to illustrate the mechanisms of plastic deformation in the materials under consideration. For that end, the sample was inserted in a specially made gripping device, to the surface of which the ceramic piezoelectric converter (TsTS-19, resonance frequency being $180 \mathrm{kHz}$ ) was fastened through the lubricant film that improved the acoustic sample-sensor contact. For AE signal recording, the acoustic complex M 400 was used, which was developed at the Institute for Mechanical Engineering Problems of the NAS of Ukraine. The facility permitted the registration of pulses varying in amplitude [11]. When testing the specimens, at certain (1 $\mathrm{s})$ intervals, the deformation parameters (applied load, gripper displacement) were synchronously registered, and the quantity of AE pulses coming to each of eight pulse-height counters-discriminators of the acoustic complex was recorded. The acquisition, processing and analysis of the experimental results were computer aided.

The texture of beryllium materials was studied by diffractometry and texture analysis on a DRON4-07 Xray diffractometer with a proportional counter in $\mathrm{CuK} \alpha$ radiation using an automatic texture-goniometer according to the Bragg-Brentano scheme.

The microstructure was examined with the metallographic microscope illuminated by polarized light, MeijiTechno, IM-7000 series; and with the scanning electron microscope.

\section{RESEARCH RESULTS}

Table 1 gives the mechanical property values of beryllium samples in relation to the AP temperature and the test temperature. Examples of the curves obtained from mechanical room-temperature tension tests and the AE-activity tests for the initial materials and after exposure to recrystallization annealing are presented in Fig. 3.

As is seen from table 1 and the tension curves obtained from the room-temperature tests (Fig. 3), the AP temperature reduction from 600 down to $500{ }^{\circ} \mathrm{C}$ leads to strength improvement by $90 \mathrm{MP}$ in the basic material. At the same time, this temperature reduction results in the reduction of percentage elongation of the metal sample after recrystallization annealing. The acoustic emission activity in the basic material after the $\mathrm{AP}$ is also two times higher for the samples obtained at a temperature of $500{ }^{\circ} \mathrm{C}$, this pointing to a higher density of dislocations in the material. 
Table 1

Mechanical properties of beryllium samples in relation to the AP temperature and the test temperature

\begin{tabular}{|c|c|c|c|c|c|c|c|}
\hline \multirow{3}{*}{$\begin{array}{c}\text { Pressing } \\
\text { temperature, }{ }^{\circ} \mathrm{C}\end{array}$} & \multirow{3}{*}{$\begin{array}{c}\text { Test } \\
\text { temperature, } \\
{ }^{\circ} \mathrm{C}\end{array}$} & \multicolumn{6}{|c|}{ Mechanical properties } \\
\hline & & \multicolumn{3}{|c|}{ Initial samples } & \multicolumn{3}{|c|}{ After annealing at $650^{\circ} \mathrm{C}, 1 \mathrm{~h}$} \\
\hline & & $\begin{array}{c}\sigma_{\mathrm{B}} \\
\mathrm{MPa}\end{array}$ & $\begin{array}{c}\sigma_{\mathrm{T}} \\
\mathrm{MPa}\end{array}$ & $\begin{array}{l}\delta \\
\%\end{array}$ & $\begin{array}{c}\sigma_{\mathrm{B}} \\
\mathrm{MPa}\end{array}$ & $\begin{array}{l}\sigma_{\mathrm{T}} \\
\mathrm{MPa}\end{array}$ & $\begin{array}{l}\delta \\
\%\end{array}$ \\
\hline \multirow{4}{*}{600} & 20 & 480 & 407 & 1.8 & 375 & 254 & 8.7 \\
\hline & 200 & 470 & 370 & 3.25 & 358 & 249 & 19.8 \\
\hline & 400 & 293 & 249 & 42.3 & 206 & 190 & 32 \\
\hline & 600 & 117 & 90 & 51 & 126 & 77 & 14.8 \\
\hline \multirow{4}{*}{500} & 20 & 570 & 505 & 1.5 & 305 & 247 & 1.2 \\
\hline & 200 & 453 & 400 & 1.6 & 276 & 231 & 3.3 \\
\hline & 400 & 286 & 255 & 23.5 & 175 & 170 & 37 \\
\hline & 600 & 126 & 83 & 37.8 & 93.3 & 90 & 24.3 \\
\hline
\end{tabular}

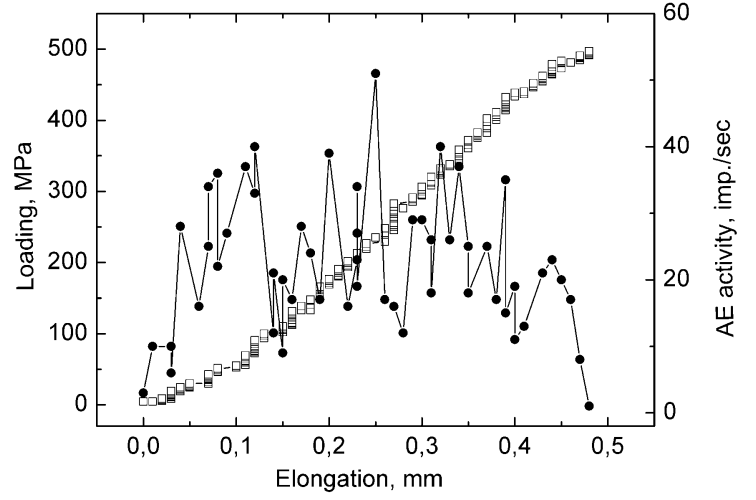

$a$ - after $\mathrm{AP}$ at $500{ }^{\circ} \mathrm{C}$

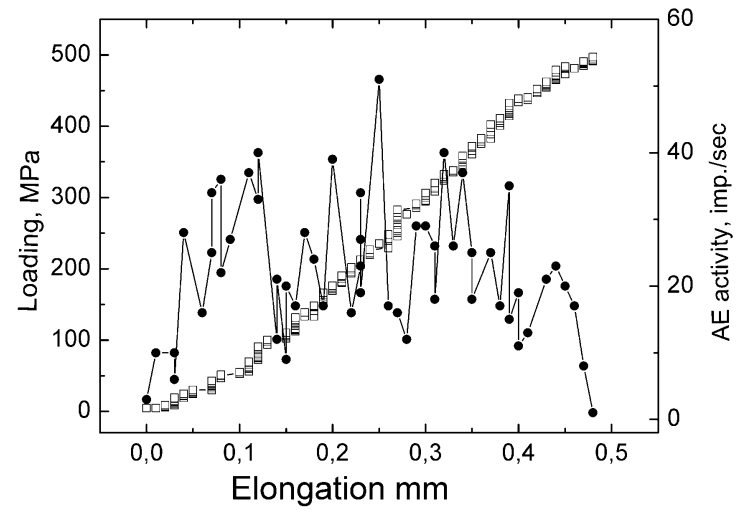

$c$ - after AP at $600{ }^{\circ} \mathrm{C}$

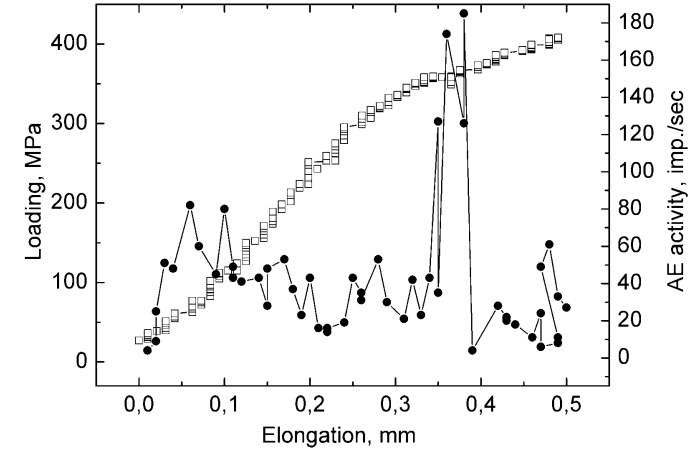

$b$ - after AP at $500{ }^{\circ} \mathrm{C}$

and recrystallization annealing at $650^{\circ} \mathrm{C}, 1 \mathrm{~h}$

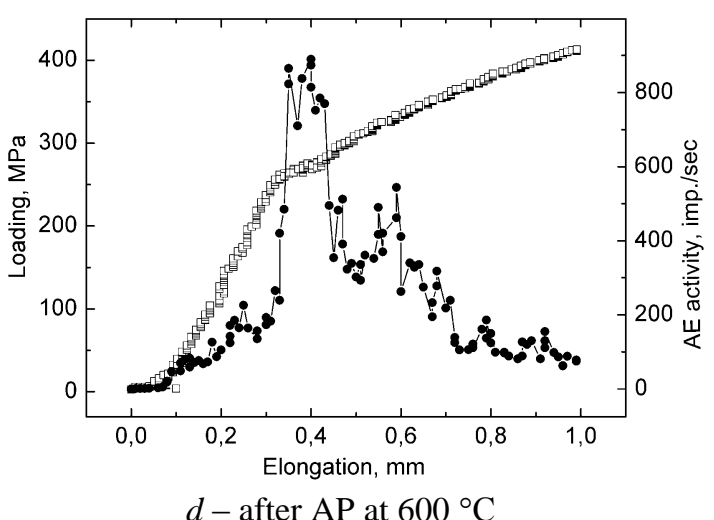

and recrystallization annealing at $650^{\circ} \mathrm{C}, 1 \mathrm{~h}$

Fig. 3. Tension ( $\square$ ) and AE activity (•) curves for initial materials and after recrystallization annealing

Table 2

Surface microhardness of extruded strips

\begin{tabular}{|c|c|c|c|}
\hline \multirow{2}{*}{$\begin{array}{c}\text { Pressing } \\
\text { temperature, } \\
{ }^{\circ} \mathrm{C}\end{array}$} & $\begin{array}{c}\text { Measurement } \\
\text { surface }\end{array}$ & Strained state & $\begin{array}{c}\text { Microhardness }\left(H_{\mu}\right), \mathrm{MPa} \\
\text { annealing } \\
650{ }^{\circ} \mathrm{C}, 1 \mathrm{~h}\end{array}$ \\
\cline { 3 - 3 } & Upper side & 2860 & \multirow{2}{*}{1750} \\
\hline \multirow{2}{*}{600} & Lower side & 2570 & \multirow{2}{*}{2230} \\
\cline { 2 - 3 } & Upper side & 3620 & \multicolumn{2}{|c|}{} \\
\cline { 2 - 3 } & Lower side & 2570 & \\
\hline
\end{tabular}




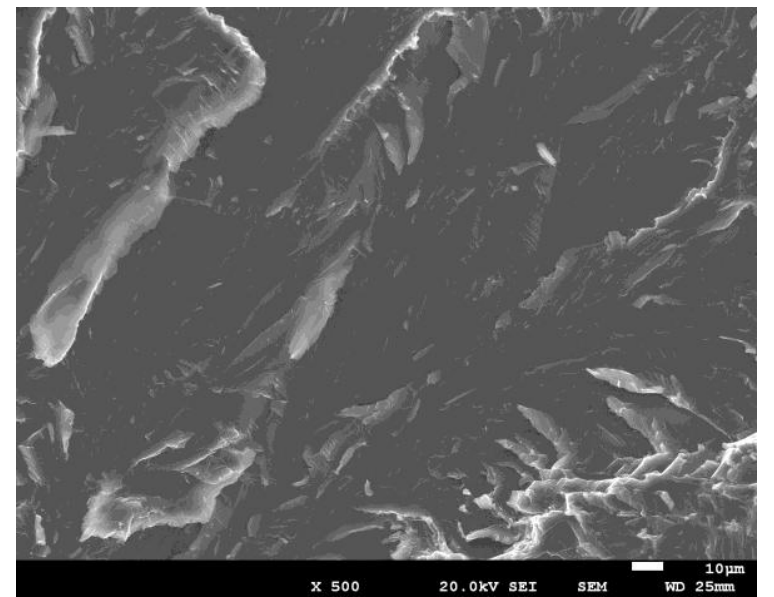

$a$

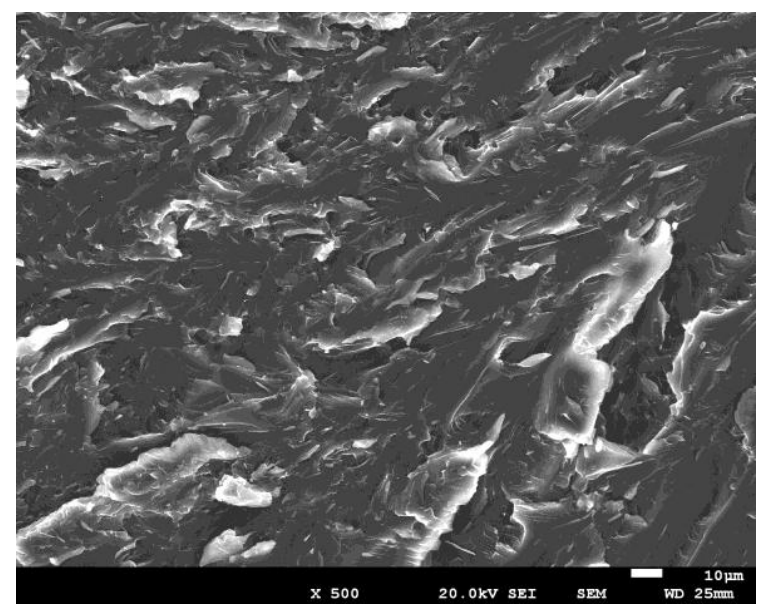

$c$

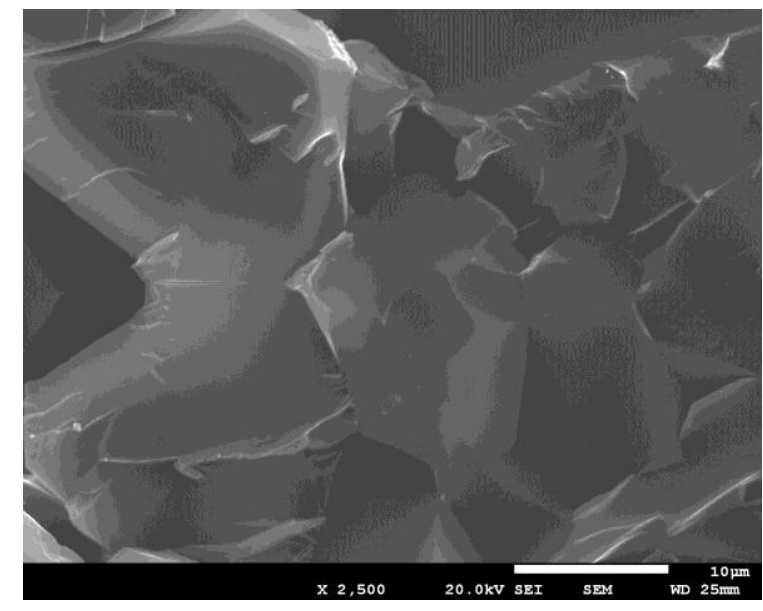

$b$

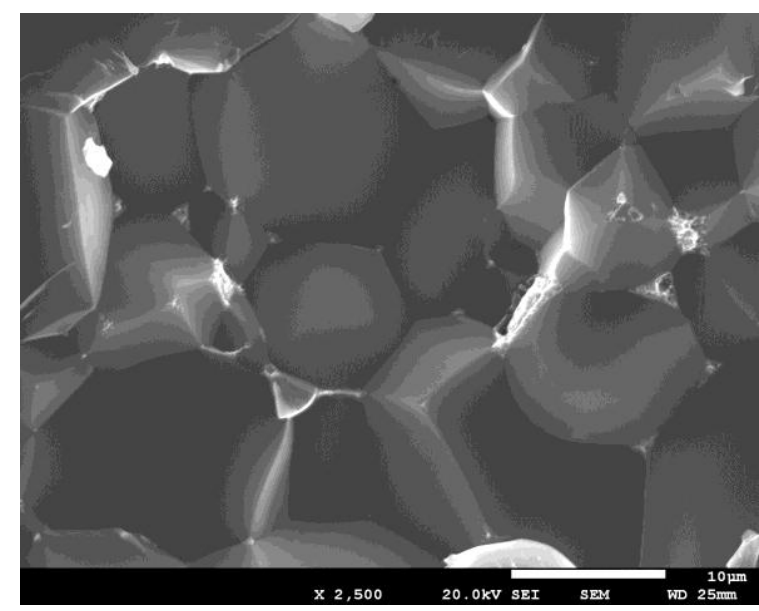

$d$

Fig. 4. SEM micrographs of fracture surface after room-temperature mechanical tests: deformation temperature $500{ }^{\circ} \mathrm{C}(\mathrm{a})$, deformation temperature $500{ }^{\circ} \mathrm{C}$ and recrystallization annealing $(b)$, deformation temperature $600{ }^{\circ} \mathrm{C}(\mathrm{c})$, deformation temperature $600{ }^{\circ} \mathrm{C}$ and recrystallization annealing $(d)$

The maximum percentage elongation for the annealed samples is observed at a test temperature of $400{ }^{\circ} \mathrm{C}$, this being typical of all beryllium materials $[7$, $9,10]$. The average values of relative elongation in room-temperature tests for all the samples after AP at $600{ }^{\circ} \mathrm{C}$ and recrystallization annealing amount to $8.7 \%$, and this is a very good result for such a brittle metal as beryllium. The tension curves, obtained at room temperature for the samples after recrystallization annealing, show a small yield plateau that correlates with a burst of AE activity (see Fig. 3,b,d).

The special features of the AE activity curves at sample deformation, viz., higher activity values and a slower decrease in the activity after the emission peak, are specified by the quantity of mobile dislocations during plastic deformation.

The microhardness data measured on the surface of the extruded strips (average values) are presented in Table 2. As the table shows, the AP temperature reduction leads to a substantial increase in $H_{\mu}$, especially on the upper side (see Fig. 1), which undergoes considerable shear deformations. On recrystallization annealing, the microhardness value decreases and levels off on both the upper and lower surfaces. The same regularity in the behavior of microhardness value on the extruded strip surfaces was observed in work [10], where the powdered metal was used as an initial material.

Fig. 4 shows the SEM micrographs of the fractured surface after mechanical testing at room temperature. As is seen from the given photos, the unannealed samples having a heavily deformed structure exhibit a brittle fracture. The structure fragments, where the fracture occurs, measure 2 to $3 \mu \mathrm{m}$. Upon recrystallization annealing, the sample failures take place mainly along the boundaries of the formed grains. The grain size in beryllium subjected to angular pressing at $600{ }^{\circ} \mathrm{C}$ and to recrystallization annealing, makes about $10 \mu \mathrm{m}$. In mechanical tests at room temperature these samples show the maximum percentage elongation values.

Fig. 5 illustrates inverse pole figures obtained from the texture analysis of beryllium samples after angular pressing at $600{ }^{\circ} \mathrm{C}$ in the state of deformation (see Fig. 5 ,a) and after recrystallization annealing (see Fig. 5,b). The inverse pole figures determined for the material in the state of deformation with angular pressing at $500{ }^{\circ} \mathrm{C}$ are shown in Fig. 5,c, and after recrystallization annealing - in Fig. 5,d. As is obvious from Fig. 5, the density of base poles in beryllium deformed at $500{ }^{\circ} \mathrm{C}$ is much higher than that after deformation at $600{ }^{\circ} \mathrm{C}$.

After annealing at $650{ }^{\circ} \mathrm{C}$ for one hour, the pole density levels off and becomes virtually the same. 

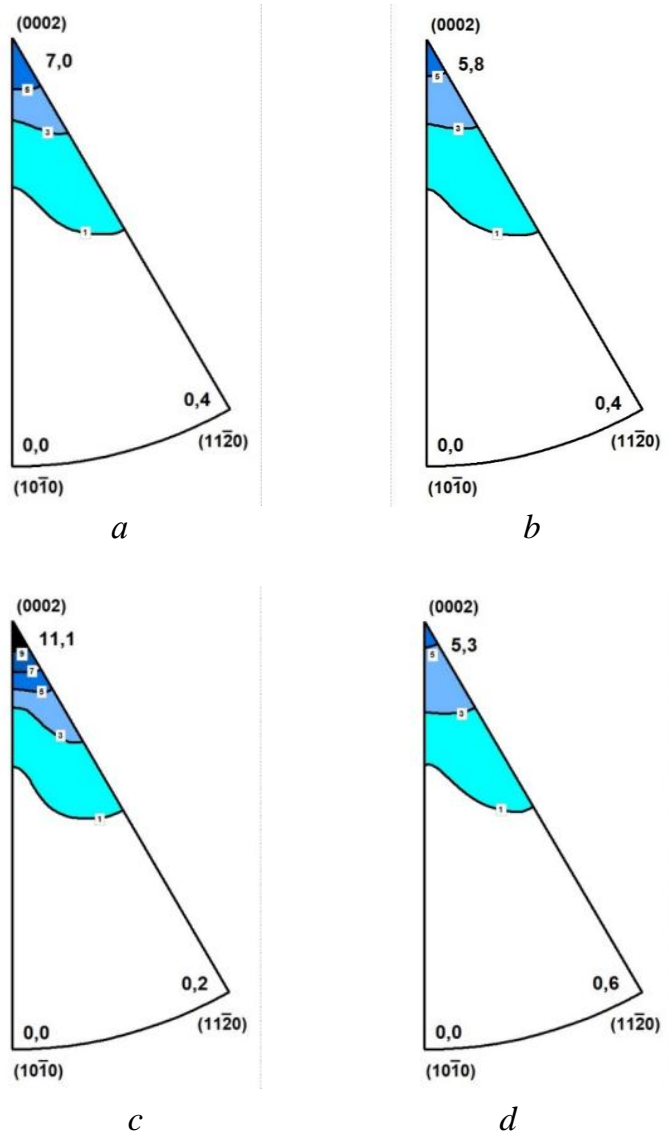

Fig. 5. Inverse pole figures by shooting

from the plane of beryllium samples. The levels of contours and the density of poles in the principal crystallographic directions are indicated

\section{CONCLUSIONS}

For the first time, angular pressing of high-purity cast beryllium has been carried out at temperatures of 600 and $500{ }^{\circ} \mathrm{C}$.

It has been shown that the degree of grain refinement during angular pressing into a strip reaches a significant value. In a single AP-deformation cycle, the grain is crushed from $3 \mathrm{~mm}$ down to $10 \mu \mathrm{m}$.

Temperature dependences of the mechanical properties of the material of extruded billets in the initial state and after recrystallization annealing at a temperature of $650{ }^{\circ} \mathrm{C}$ for one hour were studied.
It has been established that the best mechanical properties are shown by the samples of material deformed at $600{ }^{\circ} \mathrm{C}$ with subsequent annealing at $650{ }^{\circ} \mathrm{C}$ for an hour.

\section{REFERENCES}

1. F.Z. Utyashev. Modern methods of severe plastic deformation .Ufa: RIC USATU, 2008, p. 313.

2. R.Z. Valiev, I.V. Aleksandrov. 3D nanostructural metallic materials: production, structure and properties. M.: ICC “Akademkniga” publ., 2007.

3. O.A. Kaibyshev, F.Z. Utyashev. Superplasticity, grain structure refinement and processing of hard-todeform alloys. M.: "Nauka" publ., 2002.

4. Ye.G. Pashinskaya. Physical and mechanical foundations of structure refinement at combined plastic deformation. Donetsk: "Veber" publ., 2009, 352 p.

5. R.Z. Valiev, T.G. Langdon. Principles of equalchannel angular pressing as a processing tool for grain refinement // Progress in Materials Science. 2006, v. 51, p. 881-981. www.elsevier.com/locate/pmatsci

6. K. Nakashima, Z. Horita, M. Nemoto, T.G. Langdon // Mater. Sci. Eng. 2000, v. A281, p. 82.

7. I.I. Papirov, G.F. Tikhinskiy. Plastic deformation of beryllium. M.: "Atomizdat" publ., 1973, 304 p.

8. R.D. Field, K.T. Hartwig, C.T. Necker, J.F. Bingertand, S.R. Agnew. Equal-Channel Angular Extrusion of Beryllium // Metallurgical and Materials Transactions. 2002, v. 33A, p. 965.

9. A.V. Babun, A.A. Vasil'ev, K.V. Kovtun, M.P. Starolat, S.P. Stetsenko, O.V. Trembach, S.V. Khovrich. Severe plastic deformation of beryllium - structure and mechanical properties // Fizika $i$ Tekhnika Vysokikh Davleniy. 2010, N 2, p. 133-142 (in Russian).

10. A.V. Babun, A.A. Vasil'ev, M.P. Starolat, C.P. Stetsenko, O.V. Trembach, C.V. Khovrich, K.V. Kovtun. The effects of temperature and extrusion scheme on the properties of beryllium // VANT. Series "Vacuum, pure materials, superconductors". 2014, $\mathrm{N}$ 1(89), p. 10-15.

11. I.I. Papirov, P.I. Stoev, G.F. Tikhinskiy, M.I. Palatnik, M.B. Mileshkin, E.I. Muzyka // The Physics of Metals and Metallography. 1984, v. 57(2), p. 1037.

Article received 12.12.2019

\section{ИНТЕНСИВНАЯ ПЛАСТИЧЕСКАЯ ДЕФОРМАЦИЯ ВЫСОКОЧИСТОГО ЛИТОГО БЕРИЛЛИЯ}

\section{А.А. Васильев, С.П. Стеценко, Р.Л. Василенко, Д.Г. Малыхин, П.И. Стоев, С.В. Ховрич, О.В. Трембач, К.В. Ковтун}

Изучено влияние интенсивной пластической деформации на механические свойства, структуру и текстуру высокочистого литого бериллия. Впервые проведено угловое прессование высокочистого литого бериллия при температурах 600 и $500{ }^{\circ} \mathrm{C}$. Показано, что степень измельчения зерна при угловом прессовании в полосу достигает значительной величины. За один цикл деформации зерно измельчается с 3 мм до 10 мкм. Изучены температурные зависимости механических свойств материала выдавленных заготовок в исходном состоянии и после рекристаллизационного отжига при температуре $650{ }^{\circ} \mathrm{C}$ в течение одного часа. Установлено, что лучшие механические свойства имеют образцы материала, деформированного при $600{ }^{\circ} \mathrm{C}$ и после последующего отжига при $650{ }^{\circ} \mathrm{C}$ в течение часа. 
ІНТЕНСИВНА ПЛАСТИЧНА ДЕФОРМАЦІЯ ВИСОКОЧИСТОГО ЛИТОГО БЕРИЛІЮ

А.О. Васильєв, С.П. Стеценко, Р.Л. Василенко, Д.Г. Малихін, П.І. Стоєв, С.В. Ховрич, О.В. Трембач, К.В. Ковтун

Вивчено вплив інтенсивної пластичної деформації на механічні властивості, структуру і текстуру високочистого литого берилію. Вперше проведено кутове пресування високочистого литого берилію при температурах 600 i $500{ }^{\circ} \mathrm{C}$. Показано, що ступінь подрібнення зерна при кутовому пресуванні в смугу досягає значної величини. За один цикл деформації зерно подрібнюється 33 мм до 10 мкм. Вивчено температурні залежності механічних властивостей матеріалу видавлених заготовок у початковому стані і після рекристалізаційного відпалу при температурі $650{ }^{\circ} \mathrm{C}$ протягом однієї години. Встановлено, що кращі механічні властивості мають зразки матеріалу, деформованого при $600{ }^{\circ} \mathrm{C}$ та після наступного відпалу при $650{ }^{\circ} \mathrm{C}$ протягом години. 